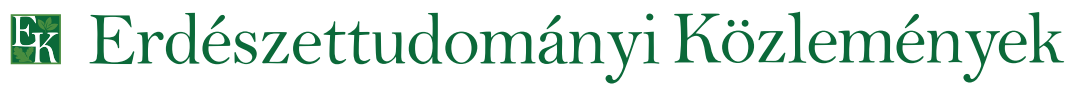

11. évfolyam 1-2. szám 2021

DOI: https://doi.org/10.17164/EK.2021.002

41-53. oldal

\section{EGYES ERDŐGAZDÁLKODÁSI TEVÉKENYSÉGEK HATÁSA A MIRIGYES BÁLVÁNYFA (AILANTHUS ALTISSIMA (MILL.) SWINGLE) TERJEDÉSÉRE MESZES HOMOKI TERMŐHELYEKEN}

\author{
Erdélyi Arnold ${ }^{1,2}$, Hartdégen Judit ${ }^{2}$, Malatinszky Ákos ${ }^{1}$ Lestyán Csaba János $^{3}$ \\ és Vadász Csaba ${ }^{4}$ \\ ${ }^{1}$ Magyar Agrár- és Élettudományi Egyetem \\ ${ }^{2}$ Magyar Madártani és Természetvédelmi Egyesület \\ ${ }^{3}$ Erdészeti szakirányitás \\ ${ }^{4}$ Kiskunsági Nemzeti Park Igazgatóság
}

\begin{abstract}
Kivonat
Tanulmányunkban a mirigyes bálványfa elöfordulási gyakoriságának és tömegességének változásait vizsgáltuk egyes fahasználatokkal, illetve tuskópászták kialakitásával érintett meszes homoki erdőállományokban (Felső-Kiskunság, Peszérierdö). Eredményeink alapján elmondható, hogy a gyérítések és tarvágások a fafaj magbankjának drasztikus mértékü aktiválódásához vezetnek. A fényellátottság hirtelen javulása, a talajbolygatás és a faanyagmozgatás egyéb hatásai miatt a vágások a fafaj felújulását és terjedését nagymértékben elősegítik. A kontroll állományokban mért spontán terjedéshez képest a fahasználatokkal érintett területeken - egyik évröl a másikra - a tömegességi mutatók akár két nagyságrenddel is nőhetnek, a korábbi szórványos előfordulást pedig az általános előfordulás válthatja fel. A mesterséges felújitások során kialakított tuskópásztákból a fafaj gyorsan terjedhet, a fiatal erdőállományokban rövid időn belül (jóval a véghasználat előtt) dominánssá válhat. A pásztákban a tuskókból és a gyökérdarabokból felsarjadó egyedek néhány éven belül már magot hozhatnak. Mindezek igazolása mellett a verticilliumos hervadás, mint hatékony biológiai védekezési lehetőség lokális vonatkozásairól is említést teszünk.
\end{abstract}

Kulcsszavak: mirigyes bálványfa, inváziós fafaj, erdészeti bolygatás, fahasználat, tuskópászta, verticilliumos hervadás

\section{IMPACTS OF DIFFERENT SILVICULTURAL PRACTICES ON THE SPREAD OF TREE OF HEAVEN (AILANTHUS ALTISSIMA (MILL.) SWINGLE) IN CALCAREOUS SAND FORESTS}

\begin{abstract}
We examined the changes in the prevalence and abundance of Tree of Heaven in several forest stands in the Peszérierdő (Central Hungary), where logging activities were carried out or previously stump deposits were made. According to our results, selective thinning and clear-cutting can have a significant effect on the activation of the seed bank of Tree of Heaven. Due to the abrupt growth of light availability, the soil disturbance and the other effects of log transport, the forest
\end{abstract}


management activities may result in a reforestation, where the Tree of Heaven becomes dominant. In comparison to the spontaneous spread measured in control stands, forest management activities resulted even in a hundred times higher growth in both the prevalences and abundances of Tree of Heaven from one year to another. In the surveyed artificial reforestations, the stump deposits proved to be the main objects where this species can regenerate from. It can resprout from its stumps and root remnants as well, then propagate within a few years and invade the intact, young stands. In addition - based on our local observations -, we also highlight the verticillium wilt as a control possibility against the Tree of Heaven.

Keywords: Tree of Heaven, invasive tree species, anthropogenic forest disturbances, logging, stump deposit, verticillium wilt

\section{BEVEZETÉS}

A mirigyes bálványfa (Ailanthus altissima (Mill.) Swingle) nemcsak hazánkban, de globális léptékben is a legjelentősebb természetvédelmi és gazdasági károkat okozó inváziós fafajok közé tartozik. 2019ben felkerült az Európai Unió inváziós listájára is (Európai Parlament és Tanács 1143/2014/EU rendelete (2014. október 22.) az idegenhonos inváziós fajok betelepítésének vagy behurcolásának és terjedésének megelőzéséröl és kezeléséről). Nemzetközi és hazai szakirodalma ennél fogva jelentősnek mondható. Magyarországi elterjedését illetve elterjesztését legrészletesebben Korda (2018) irodalmi feltárása mutatja be. A fafaj tulajdonságairól bővebben pl. Udvardy (2004), Udvardy \& Zagyvai (2012) írásaiban olvashatunk. A visszaszorítására irányuló hazai törekvéseket és tapasztalatokat Csiszár \& Korda (2017) szerkesztésében megjelent munka foglalja össze. Ugyanakkor viszonylag kevés tudományos alapossággal elemzett és szaklapokban publikált ismeretanyag áll rendelkezésünkre a bálványfa terjedése és az egyes erdészeti beavatkozások közötti összefüggésekröl.

A Bács-Kiskun megye északi részén, Kunpeszér település közigazgatási határain belül helyet foglaló Peszéri-erdő a mai napig magas természetvédelmi értéket képvisel. Az erdőssztyepp-erdő maradványokban gazdag területet azonban az inváziós fafajok nagyban veszélyeztetik. A bálványfa mellett jelentős a nyugati ostorfa (Celtis occidentalis), a kései meggy (Padus serotina) és a zöld juhar (Acer negundo) térfoglalása is. 2017 őszén az Európai Unió Life Nature alapjának támogatásával elindult az OAKEYLIFE projekt, amelynek egyik fő célkitűzése a területre nehezedő inváziós nyomás mérséklése, illetve egyes kiemelt helyszíneken megszüntetése. Az alapállapotok rögzítése hazánkban egyedülálló módon valósult meg. Az erdőrészletek, illetve egyéb részletek (kb. 900 ha) inváziós fafajokra vonatkozó felmérését ugyanis nem mintavételezéssel, hanem teljes területi lefedettségben valósítottuk meg. A beavatkozások sikerességét ezt követően újrafelmérésekkel értékeljük (bővebben: www.oakeylife.hu).

A bálványfa helyi elterjedésének történetét archív üzemtervi és recens adatok, valamint a területet régóta ismerőkkel folytatott beszélgetéseink alapján egy korábbi tanulmányunkban tártuk fel (Erdélyi et al 2019). Eredményeink alapján elmondható, hogy a fafaj első adatai a Peszéri-erdő 1937-es alapítású kísérleti erdőrészletéhez köthetök (Kolossváry 1961). Faragó (1964) is ennek szomszédságában jelzi, továbbá a leírás alapján valószínüsíthető, hogy a fafaj csak az 1930-as évek végén érkezhetett a területre. Az összegyüjtött adatok azonban egyértelműen alátámasztják, hogy a bálványfa csak az ezredforduló körül „robbanhatott be”. Jelenleg a teljes területen általánosan elöfordul, és az erdőrészletek mintegy negyedében tömegesnek mondható. Magától értetődik tehát a kérdés, hogy az exponenciális ütemü terjedés kizárólag a fafaj tulajdonságainak és a terület termőhelyi adottságainak köszönhető, vagy pedig egyes erdőgazdálkodási tevékenységek is döntő szerepet játszhatnak a tapasztalt változásokban?

Az ültetvényszerü erdőgazdálkodás (pontosabban az elsősorban idegenhonos fafajok mesterségesen létrehozott (vagy felújított), sematikus szerkezetű állományaira alapozó gazdálkodás) a Peszéri-erdőben már a 19. század közepén megjelent, de csak a 20. század elejétől kezdett meghatározóvá válni. 
Az 1960-as évektől a gépi erő alkalmazásának elterjedésével kialakultak az erdő művelésének mai napig érvényes alapvetései, technológia-sorozatai. A mesterséges felújításoknál az ültetéseket tuskózás és teljes talajelőkészítés előzi meg. A művelet technológiai háttere széles körben kutatott, s folyamatos fejlesztésekkel jellemezhető. A kiforgatott vagy kiemelt, majd pásztákba (más néven prizmákba vagy sorokba) halmozott tuskókhoz köthető későbbi folyamatokról azonban csak sporadikus, s általában tapasztalati alapú információk állnak rendelkezésre. Ismeretes, hogy a bálványfa (és más gyökérsarjképző fafajok) a tuskópásztákban újra hajthat. Ennél fogva a tuskópászta a mesterséges felújítással létrehozott erdőállomány esetében egy potenciális propagulumforrásként funkcionálhat. Fontos továbbá megemlíteni, hogy a tuskópászták általában nemcsak a famaradványokból állnak, hanem az összetolás során a feltalaj és a talajfelszín feletti biomassza egy része is ezekbe kerül. A csíraképes magok döntő többsége pontosan e két rétegben található. A Peszéri-erdő tuskópásztáin fejlődött bálványfáknál jellemzően a sarj eredetet látjuk, ugyanakkor a mag eredetet sem tudjuk mindig kizárni. Adott esetekben előfordul, hogy a fehér akác, a szürke nyár, esetleg cserjék válnak uralkodóvá a pásztákon, de a bálványfa jellemzően sokkal gyakrabban és nagyobb eréllyel teszi ezt. Jelenlegi ismereteink szerint az első tuskópásztákat az 1960-as évek közepén alakították ki a Peszéri-erdőben. A teljes talajelőkészítés során az adott területen található magbank a mélyebb talajrétegekbe kerül, így semlegesíthető. Ugyanakkor, ha a műveleteket a lehető legnagyobb alapossággal hajtják is végre (nincs csírázás), de tuskópászták kerülnek kialakításra, a bálványfa gyors visszatelepülésének lehetősége továbbra is fennáll. Azonban ezekről, a bálványfa terjedését alapvetően befolyásoló folyamatokról kvantitatív, ok-okozati összefüggésekre irányuló vizsgálati eredmények nem érhetők el a szakirodalomban.

A fafajól közismert, hogy az árnyékolást nehezen viseli (pl. Faragó 1964, Gencsi \& Vancsura 1992, Zagyvai 2006). Sokszor megfigyelhető, hogy zártabb erdők esetében a szegélyekben (leggyakrabban feltáró utak, nyiladékok mentén), esetlegesen egyéb záródáshiányos részeken (pl. természetes lékekben) mutatja a legnagyobb tömegességet. Egy fahasználat ugyanakkor az érintett terület egészén jelentős mértékben változtatja meg a záródásviszonyokat. Ennek következtében a talajfelszín illetve az újulati szint fényellátottsága nagymértékben nőhet, ami a fényigényes bálványfa számára kedvezőbb körülményeket teremthet. Ebből a szempontból (is) a tarvágás nevezhető a leginkább drasztikusnak, de az előhasználatok (gyérítések) elvégzését követően is több évig fennáll a záródáshiányos állapot. Másfelöl a fahasználatok nagymértékű talajbolygatással is járnak - különös tekintettel a gépi közelítésekre. A fent leírt bolygatástípusok és a bálványfa terjedése közötti kapcsolatra már több tanulmány rámutatott (pl. Kota et al 2007, Radtke et al 2013, Rebbeck et al 2017).

\section{Célkitűzések}

1. Kiemelt célunk volt értékelni egyes fahasználatoknak (a homoki termőhelyeken folyó erdőgazdálkodásra jellemző módon: a törzskiválasztó gyérítés illetve a tarvágás) a bálványfa előfordulási gyakoriságára és tömegességére gyakorolt hatását

2. Célunk volt az egykor teljes talajelőkészítést követően mesterségesen felújított, de újabb véghasználattal még nem érintett, tuskópásztákat tartalmazó erdőállományokban a bálványfa előfordulási gyakoriságát és tömegességét jellemezni az állománykor függvényében

3. További célunk volt a bálványfa tuskópásztákról történő terjedésének finomléptékű jellemzése a tőszámok és a pásztától vett távolság függvényében 


\section{ANYAG ÉS MÓDSZER}

Az 1. és 2. célkitüzésekre irányuló vizsgálataink során az egyes erdőrészletek vagy részterületek teljes lefedettségben kerültek felmérésre. A vizsgálati területre előzetesen egy rácsháló készült, amely $25 \times 25$ méter oldalhosszúságú négyzetekre bontja azt. Az így kapott kvadrátok képezték az alapállapot-felmérés és az újrafelmérések területi egységeit (azért nem mintavételi egységként kezeljük ezeket a területegységeket, mert nem mintavételen alapuló, hanem teljes területen megvalósuló adatgyüjtést végeztünk). A bálványfa esetében két átmérőosztály szerint, $5 \mathrm{~cm}$-es mellmagassági átmérő $\left(\mathrm{d}_{1,3}\right)$ felett, illetve alatt külön-külön számoltuk illetve becsültük a tőszámokat. $\mathrm{A} \mathrm{d}_{1,3}>5 \mathrm{~cm}$ kategóriába sorolhatók azok a mag-, illetve sarjeredetủ egyedek, amelyek túlnyomó többsége már magtermő korú (legalábbis a nőivarúak), vagy hamarosan magtermővé érhet, továbbá a nagyobb laterális gyökérzet miatt valószínűleg jóval nagyobb erélyű gyökérsarjképzésre is képes. $\mathrm{A} \mathrm{d}_{1,3}<5 \mathrm{~cm}$ kategóriába tartoznak azok az egyedek, amelyek túlélték a magonc kort, életképesek és ennél fogva potenciálisan anyafákká fejlődhetnek. Az elsősorban gyakorlati megfontolások miatt kialakított $5 \mathrm{~cm}$-es határérték természetesen egy önkényes szám, mert nem alkalmazható minden faegyedre, mivel a magtermő képességet számos tényező befolyásolhatja. Azonban - terepi tapasztalataink és a gyűjtött adatok alapján - úgy gondoljuk, hogy jó közelítést ad a magtermő képességet, ennek megfelelően a környező területekre irányuló propagulumnyomást illetően.
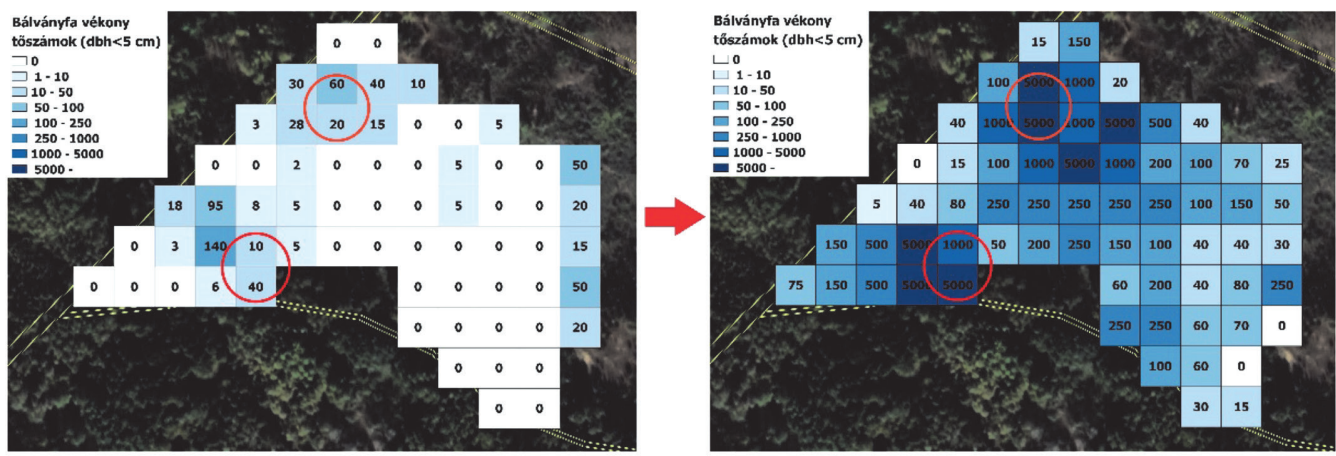

1. ábra: A mirigyes bálványfa $d_{1,3}<5 \mathrm{~cm}$ tőszám értékei a részterületes tarvágás elött (bal oldalon) és 2 év eltelte után (jobb oldalon) a sarjaztatott szürke nyáras állományban. Piros kör: $d_{1,3}>5 \mathrm{~cm}$ tövek gócpontja (potenciális magforrás). Kunpeszér $3 E$ erdőrészlet

Figure 1: Numbers of $d_{1,3}<5 \mathrm{~cm}$ stems of Tree of Heaven before clear-cut (left side) and 2 years after it (right side) in the sprouted grey poplar stand. Red circle: centre of $d_{1,3}>5 \mathrm{~cm}$ stems (potential seed source). Stand ID: Kunpeszér $3 E$

Az 1. célkitűzésre vonatkozó alapállapot felméréseket az itt vizsgált 7 erdőrészletben illetve részterületen a nyugalmi időszakokban, összesen 17,7 hektáron végeztük a 2017-2018-as illetve a 2018-2019-es nyugalmi időszakokban. Az újra-felméréseket a beavatkozást (tarvágás vagy törzskiválasztó gyérítés) követő egy vagy két vegetációs periódus után a 2019-2020-as nyugalmi időszakban végeztük el. Terepi felméréseinkkel az erdőgazdálkodó által megvalósított, erdőterv szerinti beavatkozásokat követtük le. Fontos megemlíteni, hogy a tarvágások esetében az újra-felméréseket csak azokon a területeken végeztük el, ahol az állomány felújitása sarjaztatással történt. Az összehasonlítások elsősorban a $\mathrm{d}_{1,3}<5 \mathrm{~cm}$ átmérőosztályra vonatkoznak, mert az egyes fahasználatoknál a bálványfa jellemzően tőelválasztásra kerül. Ugyanakkor az újra-felmérések során, illetve az alapállapotban rögzített tőszámok összehasonlításánál természetesen figyelembe vettük a nagyobb átmérőosztályt is (potenciális magforrás). Az előfordulási gyakoriságokban bekövetkező változást százalékos, a tőszámokat az alapállapot és az újra-felmérések esetében is becsült minimum értékekkel tüntettük fel. 
A tőszámokat a könnyebb összehasonlíthatóság érdekében 1 hektárra kifejezve adtuk meg. A vizsgálatot az 1. ábra segítségével mutatjuk be színskála kiegészítéssel. A vizsgálat kontrollterületeit a Peszéri-erdő erdőállományai közül véletlenszerűen kiválasztott, hasonló termőhelyi feltételekkel jellemezhető, fahasználattal vagy más erdészeti beavatkozással legalább 5 éve nem érintett 5 erdőrészlet vagy részterület, összesen 8,4 hektár kiterjedésben adta. Azért ilyen viszonylag nagy számú és kiterjedésű kontrollterület került kijelölésre, hogy a bálványfa fahasználatoktól független - spontán terjedésének variablitását is jellemezni tudjuk. Az érintett erdőrészletek legfontosabb üzemtervi adatait az 1. táblázatban foglaljuk össze. A faállomány típust és a termőhelytípusváltozatot tájékoztatási célból szerepeltetjük, mivel a vizsgálatba vont erdőrészletek száma nem teszi lehetővé ezek differenciális hatásainak vizsgálatát a bálványfa terjedésére vonatkozóan. Fontos továbbá megemlíteni, hogy az általunk vizsgált állományok mindegyikét sürü, közel zárt cserjeszint jellemezte. Az egyes erdőrészletekben, a bálványfa előfordulási gyakoriságában, illetve tőszámában bekövetkezett változások értékeléséhez Wilcoxon-féle páros próbát használtunk. A próba elvégezhetőségének nem feltétele a normális eloszlás.

1. táblázat: A vizsgálatokban szereplő erdőrészletek föbb üzemtervi adatai az Országos Erdőállomány Adattár alapján. Faállomány típus: A: fehér akác; HNY: hazai nyár (a Peszéri-erdőben jellemzően szürke nyár); F: fenyő (a Peszéri-erdőben erdei és fekete fenyö); EL: egyéb lomb elegy; NNY: nemes nyár fajták; KST: kocsányos tölgy. Termőhelytípus-változat: ESZTY: erdőssztyepp klíma; TVFLN: többletvizhatástól független; IDŐSZ: időszakos vízhatású (a Peszéri-erdőben megkérdőjelezhetö); HH: humuszos homok talaj; SE: sekély termöréteg; KMÉ: közepes mélységü termöréteg; H: fizikai talajféleség homok

Table 1: Main data of the examined stands from the National Forestry Database

\begin{tabular}{|c|c|c|c|c|c|}
\hline $\begin{array}{c}\text { Erdőrészlet } \\
\text { azonosító }\end{array}$ & $\begin{array}{c}\text { Érintett terület (ha)/ } \\
\text { teljes terület (ha) }\end{array}$ & $\begin{array}{l}\text { Állománykor } \\
\text { (év) }\end{array}$ & $\begin{array}{l}\text { Faállomány } \\
\text { típus }\end{array}$ & $\begin{array}{c}\text { Termöhelytípus- } \\
\text { változat }\end{array}$ & Természetesség \\
\hline \multicolumn{6}{|c|}{ 1. célkitüzésben vizsgált erdőrészletek } \\
\hline Kunpeszér $3 \mathrm{E}$ & $4,1 / 8$ & 37 & A-HNY & ESZTY-TVFLN-HH-SE-H & Kultúrerdő \\
\hline Kunpeszér $4 \mathrm{G}$ & $5,9 / 5,9$ & 35 & HNY & ESZTY-TVFLN-HH-KMÉ-H & Átmeneti erdő \\
\hline Kunpeszér 6 B & $2,3 / 2,3$ & 55 & HNY-A & ESZTY-TVFLN-HH-KMÉ-H & Átmeneti erdő \\
\hline Kunpeszér $8 \mathrm{C}$ & $1 / 2,9$ & 53 & HNY-F & ESZTY-IDÖSZ-HH-SE-H & Származék erdő \\
\hline Kunpeszér10 C & $2,4 / 2,4$ & 40 & HNY-EL & ESZTY-IDÖSZ-HH-KMÉ-H & Származék erdő \\
\hline Kunpeszér11 B & $1,2 / 2,2$ & 16 & HNY-A & ESZTY-TVFLN-HH-KMÉ-H & Átmeneti erdő \\
\hline Kunpeszér14 A2 & $2,7 / 3,6$ & 37 & $\mathrm{~A}$ & ESZTY-TVFLN-HH-KMÉ-H & Kultúrerdő \\
\hline Kunpeszér $23 \mathrm{D}$ & $1,9 / 1,9$ & 22 & NNY-A & ESZTY-TVFLN-HH-KMÉ-H & Kultúrerdő \\
\hline Kunpeszér $23 \mathrm{E}$ & $0,6 / 0,6$ & 22 & HNY-A & ESZTY-TVFLN-HH-KMÉ-H & Átmeneti erdő \\
\hline Kunpeszér 261 & $1,7 / 1,7$ & 18 & HNY & ESZTY-TVFLN-HH-KMÉ-H & Átmeneti erdő \\
\hline Kunpeszér 27 B & $1,7 / 1,7$ & 30 & A-EL & ESZTY-TVFLN-HH-KMÉ-H & Átmeneti erdő \\
\hline Kunpeszér $27 \mathrm{E}$ & $0,6 / 7,2$ & 27 & HNY-A & ESZTY-TVFLN-HH-KMÉ-H & Átmeneti erdő \\
\hline \multicolumn{6}{|c|}{ 2.-3. célkitüzésben vizsgált erdőrészletek } \\
\hline Kunpeszér 5 D & $2,4 / 2,4$ & 5 & HNY & ESZTY-TVFLN-HH-SE-H & Származék erdő \\
\hline Kunpeszér $7 \mathrm{~K}$ & $0,8 / 0,8$ & 5 & HNY & ESZTY-TVFLN-HH-KMÉ-H & Származék erdö \\
\hline Kunpeszér 9 B & $1,8 / 1,8$ & 4 & HNY-EL & ESZTY-TVFLN-HH-KMÉ-H & Származék erdő \\
\hline Kunpeszér11 F & $0,8 / 0,8$ & 16 & HNY-NNY & ESZTY-TVFLN-HH-SE-H & Átmeneti erdő \\
\hline Kunpeszér11 J & $2,2 / 2,2$ & 14 & HNY-NNY & ESZTY-TVFLN-HH-SE-H & Átmeneti erdő \\
\hline Kunpeszér11 L & $1,3 / 1,3$ & 17 & HNY-NNY & ESZTY-TVFLN-HH-KMÉ-H & Származék erdő \\
\hline Kunpeszér14 B & $1,9 / 1,9$ & 26 & HNY & ESZTY-TVFLN-HH-KMÉ-H & Származék erdő \\
\hline Kunpeszér19 B & $6,7 / 6,7$ & 7 & HNY & ESZTY-TVFLN-HH-KMÉ-H & Származék erdő \\
\hline Kunpeszér $20 \mathrm{D}$ & $4,5 / 4,5$ & 26 & HNY-EL & ESZTY-TVFLN-HH-KMÉ-H & Származék erdő \\
\hline Kunpeszér $20 \mathrm{~J}$ & $1,6 / 1,6$ & 7 & HNY-NNY & ESZTY-TVFLN-HH-SE-H & Származék erdő \\
\hline Kunpeszér $25 \mathrm{C}$ & $1,9 / 2,7$ & 4 & HNY-KST & ESZTY-IDÖSZ-HH-KMÉ-H & Származék erdő \\
\hline Kunpeszér $26 \mathrm{~B}$ & $3,2 / 12$ & 4 & HNY-A & ESZTY-IDÖSZ-HH-KMÉ-H & Kultúrerdő \\
\hline Kunpeszér $27 \mathrm{~F}$ & $1 / 1$ & 22 & NNY-EL & ESZTY-TVFLN-HH-KMÉ-H & Faültetvény \\
\hline
\end{tabular}


A 2. célkitüzés esetében a Peszéri-erdőben található teljes talajelökészitést követően mesterségesen felújított, de véghasználattal még nem érintett, tuskópásztákat tartalmazó erdőállományok közül azokat választottuk ki, ahol biztosan tudtuk, hogy a korábbi állományban a bálványfa előfordult és a felméréskor a tuskópásztákon megtalálható volt. A vizsgált erdőrészleteket, illetve részterületeket koruk szerint rendeztük. Főfafajuk nagyrészt szürke nyár, kisebb részt nemes nyárak. Összterületük 30,1 ha. Az érintett erdőrészletek főbb üzemtervi adatait az 1. táblázat tartalmazza. A bálványfa tömegességi viszonyait az előfordulási gyakoriság és a tőszámok együttes figyelembevételével értékeltük. A tőszám értékeket 1 hektárra vonatkozóan adtuk meg.

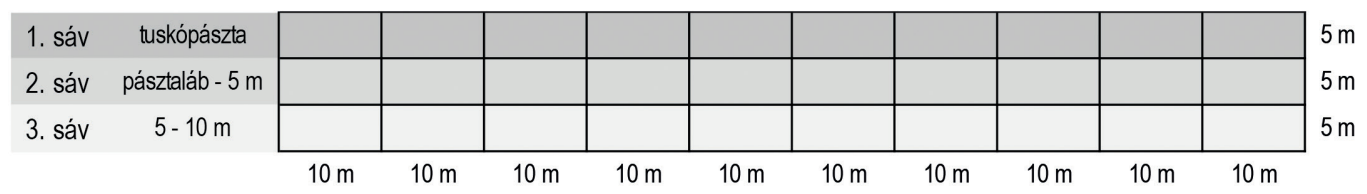

2. ábra: A mirigyes bálványfa tuskópásztákról történő terjedésének vizsgálati elrendezése

Figure 2: The set-up of the field survey to examine the spreading of Tree of Heaven from stump deposits

A 3. célkitüzés esetében a tuskópásztákról történő terjedés vizsgálatát mintavétellel végeztük egy 7 éves és egy 26 éves, egymással szomszédos helyzetü szürke nyáras mesterséges erdőfelújításban (Kunpeszér $20 \mathrm{~J}$ és Kunpeszér 20 D). A vizsgált tuskópásztákat és a csatlakozó állományrészeket három sávra, a sávokat pedig 10 méter hosszúságú és 5 méter szélességű szakaszokra osztottuk. A három sáv a következőket jelentette: 1) a pászta (némileg változó szélességü, de átlagosan 5 méter széles) sávja; 2) a pásztalábtól 5 méter szélességben futó sáv; 3) a pásztalábtól 5 méteres távolságra kezdődő, 5 méter széles sáv (2. ábra). Mindegyik sávból 10-10 szakaszt mértünk fel, ami sávonként $500 \mathrm{~m}^{2}$ felmérését jelentette. A fiatal állomány esetében egy pásztát és annak mindkét oldalát, míg a fiatal-középkorú állomány esetében három pásztát és 1-1 oldalukat vizsgáltuk. A bálványfa tőszám értékeinek rögzítésénél továbbá elkülönítettük $a d_{1,3}>10 \mathrm{~cm}$ töveket. $A d_{1,3}<5 \mathrm{~cm}$ átmérőosztálynál a 250 -es és 500 -as becsült értékek minimum tőszámoknak tekintendők. Az eredményeket a tőszámokon keresztül mutatjuk be, azonban a könnyebb érzékelhetőség miatt színskálát is alkalmaztunk.

\section{EREDMÉNYEK ÉS MEGVITATÁSUK}

\section{Fahasználatok}

A rögzített alapállapotokhoz képest minden általunk vizsgált, fahasználattal érintett területen a bálványfa előfordulási gyakorisága szignifikánsan nőtt ( $W=42, p=0.02966)$, tőszámaiban pedig szintén szignifikáns növekedés következett be (W=42, $p=0,02895)$. A kontroll állományokban a bálványfa előfordulási gyakorisága szignifikánsan nem nőtt ( $W=14, p=0.8413)$, illetve a tőszámok általában csak kisebb, összességében nem szignifikáns mértékeben emelkedtek $(\mathrm{W}=14, \mathrm{p}=0,4020)$ (2. táblázat, példa: 1. ábra). További elemzésekért lásd Erdélyi et al 2021.

Az egyes fahasználatoknak - mind az előhasználatoknak, mind a véghasználatoknak - tehát egyértelműen pozitív hatása van a fafaj terjedésére nézve. Az esetek között azonban érdekes különbségek adódtak. A nagyszámú $d_{1,3}>5 \mathrm{~cm}$ egyedet tartalmazó állományoknál előfordult olyan, ahol a tarvágás, illetve gyérítés utáni tőszámnövekedés „pusztán” néhányszoros. Ugyanakkor a $\mathrm{d}_{1,3}>5 \mathrm{~cm}$ egyedeket nagyon alacsony számban tartalmazó erdőrészleteknél is láthatunk olyat, hogy a bálványfa tőszámában bekövetkezett növekedés két nagyságrendre tehető. 
2. táblázat: Az egyes fahasználatok hatása a mirigyes bálványfára

Table 2: Effects of certain harvest treatments on the Tree of Heaven

\begin{tabular}{|l|l|c|c|c|c|c|c|}
\hline $\begin{array}{c}\text { Erdörészlet } \\
\text { azonosító }\end{array}$ & Fahasználat & $\begin{array}{c}\mathrm{d}_{1,3}>\mathbf{5} \mathrm{cm} \\
\text { tôszám/ha }\end{array}$ & $\begin{array}{c}\text { Elöfordulási } \\
\text { gyakoriság } \\
(\%)(\text { elötte) }\end{array}$ & $\begin{array}{c}\text { Elöfordulási } \\
\text { gyakoriság } \\
(\%)(\text { (utána) }\end{array}$ & $\begin{array}{c}\mathrm{d}_{1,3}<5 \mathrm{~cm} \\
\text { töszám } / \mathrm{ha} \\
(\mathbf{e l o ̈ t t e )}\end{array}$ & $\begin{array}{c}\mathrm{d}_{1,3}<5 \mathrm{~cm} \\
\text { töszám / ha } \\
\text { (utána) }\end{array}$ & $\begin{array}{c}\mathrm{d}_{1,3}<5 \mathrm{~cm} \\
\text { töszám } \\
\text { növekedés }\end{array}$ \\
\hline Kunpeszér 3 E & Tarvágás & 50 & 59 & 97 & 175 & 12000 & $68,5 \mathrm{x}$ \\
\hline Kunpeszér 4 G & Tarvágás & 110 & 77 & 99 & 1600 & 4000 & $2,5 \mathrm{x}$ \\
\hline Kunpeszér 8 C & Tarvágás & 250 & 100 & 100 & 5000 & 42000 & $8,4 \mathrm{x}$ \\
\hline Kunpeszér14 A & Tarvágás & 3 & 17 & 98 & 15 & 4000 & $266,6 \mathrm{x}$ \\
\hline Kunpeszér 26 1 & Gyérítés & 9 & 59 & 69 & 80 & 265 & $3,3 \mathrm{x}$ \\
\hline Kunpeszér 27 B & Gyérítés & 3 & 54 & 82 & 60 & 235 & $3,9 \mathrm{x}$ \\
\hline Kunpeszér 27 E & Gyérítés & 64 & 30 & 100 & 200 & 38500 & $192,5 \mathrm{x}$ \\
\hline Kunpeszér 6 B & Kontroll & 127 & 98 & 100 & 1700 & 1200 & $0,7 \mathrm{x}$ \\
\hline Kunpeszér11 B & Kontroll & 157 & 87 & 100 & 2800 & 6000 & $2,1 \mathrm{x}$ \\
\hline Kunpeszér10 C & Kontroll & 40 & 44 & 65 & 320 & 330 & $1 \mathrm{x}$ \\
\hline Kunpeszér 23 D & Kontroll & 7 & 62 & 50 & 510 & 1100 & $2,1 \mathrm{x}$ \\
\hline Kunpeszér 23 E & Kontroll & 28 & 84 & 92 & 1500 & 5000 & $3,3 \mathrm{x}$ \\
\hline
\end{tabular}

A tarvágással érintett területeken a $\mathrm{d}_{1,3}>5 \mathrm{~cm}$ átmérőosztályba tartozó tövek száma értelemszerủen nullára csökken, ami a maggal történő propagulumnyomás időszakos megszünését jelenti. Azonban ez a jelenség - figyelembe véve a vékonyabb tövek számának drasztikus növekedését - csak néhány évig tart, amely időszakot követően a propagulumnyomás a fahasználatot megelőző időszakhoz képest elöre láthatólag többszörösére fog nőni.

A területen történő tarvágásokban a nagyobb törzsek vonszolása, adott (bár ritkán előforduló) esetekben irányitott döntése (húzása) és más jellegü faanyagmozgatások döntően gépi erővel (jellemzően traktor) történnek. A laza homoktalajok esetében még a kíméletes közelítést biztosító eszközök alkalmazása mellett is jelentős talajbolygatás a vágásterület teljes területét érinti. A gyérítéseknél azonban a faanyagot kézi erővel viszik ki és rakják fel kiskocsira, amit a nehézgép keskeny közelitő nyomon vontat ki a rakodóig. A tarvágások és gyéritések következtében a fényellátottság nagymértékben javul, azonban ez nem csak a faállomány teljes vagy részbeni eltünésére vezethető vissza. A Peszéri-erdő erdőállományait általában közel zárt és meglehetősen sürü cserjeszint jellemzi. A fahasználatok során a cserjeegyedek azonban többségükben tőelválasztásra kerülnek. A lombszintek és különösen a cserjeszint záródásában bekövetkező csökkenés tehát együttesen járul hozzá a bálványfa számára kedvezőbb feltételek kialakulásához - a talajbolygatások mellett.

Adöntések és faanyagmozgatások során a fafaj lependék termései az anyafáktól messze elkerülhetnek. Ezt alapesetben a szél általi terjesztésre adaptálódott terméstípus biztosítja, de a fahasználatok folyamán a magok számos egyéb úton (pl. a kerékbe ragadt sárban vagy a vágástéri hulladék között) is új területekre juthatnak. A vágásterületeken a fafaj tőszámaiban bekövetkező nagyságrendi növekedést döntő többségben a mag eredetű egyedek adják. Ezt a kisméretủ egyedek kihúzásával rendszeresen teszteltük. Fontos megemlíteni, hogy - saját, egyelöre nem publikált tapasztalataink alapján - a bálványfa magoncok nagyobb része az első vegetációs periódus során természetes úton elpusztul. Azonban mi a felmérések során az első, vagy második vegetációs periódus utáni, életképes egyedeket vettük csak számításba. Ez a terepen jól látható, még az elfagyással érintett egyedek esetében is (a talajfelszín feletti közvetlen hajtásrész kérge ép, nem "hámlik”, továbbá élénkebb, szalmasárga színű, mint a felette elfagyott rész). A bálványfa fagyérzékenységéről az elmúlt bő két évszázad során sokan írtak (in Korda 2018). A magonc fázist túlélt egyedeknél gyakran megfigyelhető 
a hajtásvégek elfagyása, azonban ez nem feltétlenül jelenti azok pusztulását is. A következő vegetációs periódusban ugyanis vagy közvetlenül az elhalt hajtásrész alól, vagy a gyökfőről újra sarjadnak. Továbbá megfigyeltük, hogy már 1 éves korában is képes gyökérsarjat hozni. A Kunpeszér 3 E és $4 \mathrm{G}$ erdőrészletek esetében két, egymást követő újra-felmérést is elvégeztünk. Minden nyugalmi időszakban jól látható volt egyes új tövek elfagyása, majd a vegetációs periódusban való újra sarjadása. Ezt a tőszám értékek is alátámasztják, mert nem csökkenést, hanem kismértékü emelkedést mutattak.

A tarvágással érintett erdőrészletek közül csak a Kunpeszér $4 \mathrm{G}$ erdőrészletben nem nőttek meg nagyságrendekkel a tőszámok - annak ellenére sem, hogy a vastagabb tövek száma nagy volt. Ennek oka komplex, azonban a négy sarjaztatással felújított erdőrészlet közül egyértelműen itt volt a legsikeresebb a szürke nyár és a fehér akác felújítása illetve a legnagyobb erélyű a cserjék felsarjadása. A tarvágást követő első vegetációs periódus végére már sürü, 2-3 m magas fiatalos alakult ki. A bálványfa kiugróan magas tőszámokkal csak a záródáshiányos részeken és a szegélyeken fordult elő. A tapasztaltak (részben) megint csak a fafaj fényigényességére vezethetők vissza. Azt azonban itt is el lehet mondani, hogy a következő vágásfordulóig a magtermő egyedek száma, illetve ennek megfelelően a propagulumnyomás itt is várhatóan nagyobb lesz, mint a tarvágás előtti időpontban.

Az előbb említett terület ellenpéldájának a Kunpeszér 14 A erdőrészlet mondható. Ebben alig volt jelen a fafaj, míg a fahasználatok után általánosan elterjedtté vált. Az ok valószínűleg itt is összetett, de fontos szerepet játszhatott az, hogy a szomszédos erdőrészletek határán számos magtermő egyed sorakozott és a közelítő nyom is részben itt futott. A magok többsége (gyakran egyben az egész magcsokor) általában az anyafa körül hullik le, így a faanyagmozgatás során nagy számban kerülhettek be a vágásterületre. Másfelöl az elmúlt évek alatt kívülről érkező, de még nyugvó lependékek is csírázásnak indulhattak a záródáshiány kialakulása miatt.

A szomszéd terület szerepének fontosságára világít rá a Kunpeszér 26 I és $27 \mathrm{~B}$ erdőrészlet is. Ezekben alacsony volt $\mathrm{a}_{1,3}>5 \mathrm{~cm}$ kategóriához tartozó tőszám és csak néhányszoros növekedés volt tapasztalható a gyérítések után. A környező területekről azonban gyakorlatilag hiányoztak a magtermő faegyedek.

\section{Tuskópászták}

Eredményeink alapján a bálványfa a tuskópásztás mesterséges erdőfelújitások teljes területén nagyon gyorsan megjelenhet és akár néhány éven belül tömegessé válhat (3. táblázat). Az általunk vizsgált összes, 10 évnél idősebb erdőállományban nagy tőszámokkal volt jelen, de a fiatalabb erdőállományokban is előfordult a bálványfa tömeges jelenléte.

Terepi tapasztalataink szerint a tömeges előfordulás azonban nemcsak a pászták területére korlátozódhat. Gyakran előfordul, hogy a mesterséges felújitás kivitelezése során az egyes pászták mellett, vagy az állományszegélyeknélüres tér marad. Ennek elsősorban gyakorlati okai vannak (pl. közelítő út gépiápolásokhoz, nehézgép fordulását biztosító területrészek). A faállománnyal nem borított, üres tereket a versenytársak hiánya, illetve a nagy fényellátottság miatt a fafaj gyorsan kihasználja. A fiatal állományokban a tőszámok kiugró értékei - az egyes pásztaszakaszok mellett - jellemzően ezekhez köthetők. Eddigi tapasztalataink szerint a pásztán és a pászták közvetlen szomszédságában található gócpontok leginkább sarj eredetűek. A tuskópásztákból fejlődő nagyszámú sarj mellett azonban megjelenhetnek mag eredetű egyedek is. Az anyafák viszont nemcsak a szomszédos állományokban keresendők, hanem már néhány év elteltével magukon a tuskópásztákon is. A felmért állományokban a kívülről vagy a tuskópásztákról származó mag eredetű egyedek arányát nem lehet biztosan megállapítani.

Az általunk vizsgált fiatal és középkorú állományokban rögzített bálványfa tőszám értékek (4-5. táblázat) jól rávilágítanak a tuskópászták nagy jelentőségére a terjedés kiindulási helyét tekintve. $A z 5 \mathrm{~cm}<\mathrm{d}_{1,3}<10 \mathrm{~cm}$ 
és a $\mathrm{d}_{1,3}>10 \mathrm{~cm}$ átmérőosztályokban a legnagyobb tőszámok az esetek döntő többségében a pásztákhoz köthetök. A fiatal állományban még csak az $5 \mathrm{~cm}<\mathrm{d}_{1,3}<10 \mathrm{~cm}$ átmérőosztály van jelen, és az ebbe tartozó faegyedek szinte kizárólag a pásztán találhatók. Az idősebb állományban azonban ez a kategória már általában közvetlenül a pászta melletti, ritkábban a pásztától 5-10 méteres távolságban található szakaszokban is magas értékeket mutat. $\mathrm{Ad}_{1,3}<5 \mathrm{~cm}$ átmérőosztály tőszámai esetében sokkal nagyobb értékeket láthatunk a pászta mellett, illetve a pásztától távolabb eső sávban is. $A \mathrm{~d}_{1,3}<5 \mathrm{~cm}$ átmérőosztályba tartozó egyedek száma továbbá pozitívan korrelál a pásztán található magasabb átmérőosztályok tőszámaival. A gyűjiött adatok tehát a fafaj pásztáról az állományba történő beterjedését alátámasztják. Ez részben minden bizonnyal sarjól történik, azonban a pásztán felnővő sarjak már korán magot is hozhatnak, ami viszont nagyobb távolságra is kerülhet. A pászta melletti, illetve a pásztától távolabb eső sáv között a $\mathrm{d}_{1,3}<5 \mathrm{~cm}$ átmérőosztály tőszámai között valószínűsíthetően emiatt nincs érdemi különbség. További elemzésekért lásd Erdélyi et al 2021.

3. táblázat: A mirigyes bálványfa tőszám értékei tuskópásztás, mesterségesen felújitott állományokban az állománykor függvényében

Table 3: Number of stems of Tree of Heaven in artificially reforested stands with stump deposits regarding to their age

\begin{tabular}{|l|c|c|c|c|}
\hline $\begin{array}{c}\text { Erdörészlet } \\
\text { azonosító }\end{array}$ & $\begin{array}{c}\text { Állománykor } \\
\text { (év) }\end{array}$ & $\begin{array}{c}\text { Elöfordulási } \\
\text { gyakoriság } \\
(\%)\end{array}$ & $\begin{array}{c}\mathrm{d}_{1,3}>\mathbf{5 m} \\
\text { töszám/ha }\end{array}$ & $\begin{array}{c}\mathrm{d}_{1,3}<5 \mathrm{~cm} \\
\text { töszám/ha }\end{array}$ \\
\hline Kunpeszér 9 B & 4 & 90 & 7 & 2300 \\
\hline Kunpeszér25 C & 4 & 63 & 0 & 100 \\
\hline Kunpeszér26 B & 4 & 67 & 28 & 228 \\
\hline Kunpeszér5 D & 5 & 87 & 53 & 700 \\
\hline Kunpeszér 7 K & 5 & 100 & 3 & 2000 \\
\hline Kunpeszér19 B & 7 & 66 & 168 & 270 \\
\hline Kunpeszér20J & 7 & 88 & 250 & 4250 \\
\hline Kunpeszér11 J & 14 & 94 & 530 & 2000 \\
\hline Kunpeszér11 F & 16 & 90 & 523 & 6500 \\
\hline Kunpeszér11 L & 17 & 90 & 93 & 2700 \\
\hline Kunpeszér27 F & 22 & 87 & 155 & 2000 \\
\hline Kunpeszér14 B & 26 & 73 & 331 & 8100 \\
\hline Kunpeszér 20 D & 26 & 100 & 00 \\
\hline
\end{tabular}

4. táblázat: A mirigyes bálványfa tőszám értékei a tuskópásztákon és a csatlakozó állományrészekben, 26 éves szürke nyáras mesterséges erdőfelújitásban (Kunpeszér 20 D erdőrészlet). A tőszám értékek a három átmérőosztály szerint rendezettek

Table 4: Number of stems of Tree of Heaven on stump deposits and in the adjoining stands, in a 26 year old grey poplar artificial reforestation (stand ID: Kunpeszér 20 D). Stem numbers are organized in three diameter classes

\begin{tabular}{|c|c|c|c|c|c|c|c|c|c|c|c|c|c|c|c|c|c|c|c|c|c|c|c|c|c|c|c|c|c|c|}
\hline $\mathrm{d}_{1,3}>10 \mathrm{~cm}$ & \multicolumn{10}{|c|}{ 1. minta (tőszámok) } & \multicolumn{10}{|c|}{ 2. minta (tőszámok) } & \multicolumn{10}{|c|}{ 3. minta (tőszzámok) } \\
\hline Tuskópàszza & 0 & 0 & 2 & 0 & 2 & 0 & 0 & 0 & 0 & 0 & 1 & 1 & 2 & 0 & 1 & 1 & 2 & 3 & 2 & 3 & 3 & 4 & 12 & 6 & 7 & 2 & 2 & 3 & 6 & 2 \\
\hline $0-5$ méter & 0 & 1 & 0 & 0 & 0 & 0 & 0 & 0 & 0 & 0 & 0 & 0 & 0 & 2 & 0 & 0 & 1 & 0 & 0 & 2 & 3 & 0 & 1 & 3 & 0 & 0 & 0 & 1 & 2 & 2 \\
\hline 5-10 méter & 0 & 1 & 0 & 0 & 0 & 0 & 0 & 0 & 0 & 0 & 2 & 1 & 0 & 0 & 0 & 0 & 1 & 1 & 0 & 0 & 0 & 1 & 0 & 0 & 0 & 0 & 0 & 0 & 0 & 0 \\
\hline $10 \mathrm{~cm}>d_{1,3}>5 \mathrm{~cm}$ & \multicolumn{10}{|c|}{ 1. minta (tőszámok) } & \multicolumn{10}{|c|}{ 2. minta (töszámok) } & \multicolumn{10}{|c|}{ 3. minta (tốszámok) } \\
\hline Tuskópászta & 1 & 10 & 7 & 6 & 1 & 2 & 1 & 5 & 3 & 13 & 8 & 3 & 6 & 3 & 11 & 11 & 5 & 12 & 19 & 23 & 6 & 16 & 17 & 18 & 13 & 7 & 8 & 14 & 12 & 13 \\
\hline $0-5$ méter & 0 & 2 & 0 & 1 & 0 & 0 & 2 & 0 & 0 & 1 & 2 & 3 & 1 & 2 & 2 & 2 & 1 & 3 & 8 & 15 & 3 & 4 & 0 & 3 & 2 & 3 & 3 & 3 & 2 & 4 \\
\hline 5-10 méter & 3 & 3 & 3 & 1 & 0 & 0 & 1 & 0 & 0 & 0 & 2 & 5 & 1 & 1 & 0 & 3 & 1 & 6 & 8 & 3 & 0 & 2 & 0 & 0 & 0 & 5 & 0 & 2 & 2 & 2 \\
\hline $\mathrm{d}_{1,3}<5 \mathrm{~cm}$ & \multicolumn{10}{|c|}{ 1. minta (töszámok) } & \multicolumn{10}{|c|}{ 2. minta (töszámok) } & \multicolumn{10}{|c|}{ 3. minta (tốszámok) } \\
\hline Tuskópàszta & 1 & 25 & 90 & 80 & 50 & 30 & 25 & 100 & 30 & 40 & 150 & 100 & 150 & 250 & 590 & 250 & 500 & 600 & 250 & 250 & 500 & 250 & 250 & 250 & 250 & 250 & 250 & 250 & 800 & 250 \\
\hline $0-5$ méter & 2 & 30 & 80 & 45 & 20 & 2 & 25 & 65 & 20 & 10 & 200 & 250 & 200 & 100 & 80 & 100 & 100 & 120 & 100 & 250 & 60 & 120 & 100 & 80 & 70 & 50 & 100 & 100 & 80 & 250 \\
\hline 5-10 méter & 15 & 50 & 130 & 45 & 8 & 10 & 25 & 45 & 20 & 20 & 220 & 150 & 230 & 100 & 130 & 150 & 120 & 150 & 220 & 250 & 120 & 125 & 130 & 100 & 125 & 160 & 150 & 85 & 140 & 230 \\
\hline
\end{tabular}


5. táblázat: A mirigyes bálványfa tőszám értékei a tuskópásztákon és a csatlakozó állományrészekben, 7 éves szürke nyáras mesterséges erdőfelújitásban (Kunpeszér $20 \mathrm{~J}$ erdőrészlet). A tőszámértékek a két átmérőosztály szerint rendezettek

Table 5: Number of stems of Tree of Heaven on stump deposits and in the adjoining stands, in a 7 year old grey poplar artificial reforestation (stand ID: Kunpeszér $20 \mathrm{~J}$ ). Stem numbers are organized in two diameter classes

\begin{tabular}{|c|c|c|c|c|c|c|c|c|c|c|c|c|c|c|c|c|c|c|c|c|}
\hline $10 \mathrm{~cm}>d_{1,3}>5 \mathrm{~cm}$ & \multicolumn{10}{|c|}{ 1. minta (tőszámok) } & \multicolumn{10}{|c|}{ 2. minta (tőszámok) } \\
\hline Tuskópászta & 11 & 8 & 10 & 9 & 10 & 10 & 8 & 5 & 4 & 4 & 11 & 8 & 10 & 9 & 10 & 10 & 8 & 5 & 4 & 4 \\
\hline $0-5$ méter & 0 & 0 & 0 & 0 & 0 & 0 & 0 & 0 & 0 & 0 & 2 & 0 & 0 & 0 & 0 & 1 & 0 & 0 & 0 & 0 \\
\hline 5-10 méter & 0 & 0 & 0 & 0 & 0 & 0 & 0 & 0 & 0 & 0 & 0 & 0 & 0 & 0 & 0 & 0 & 0 & 0 & 0 & 0 \\
\hline $\mathbf{d}_{1,3}<5 \mathrm{~cm}$ & \multicolumn{10}{|c|}{ 1. minta (tőszámok) } & \multicolumn{10}{|c|}{ 2. minta (tőszámok) } \\
\hline Tuskópászta & 80 & 120 & 50 & 45 & 50 & 15 & 16 & 20 & 15 & 20 & 80 & 120 & 50 & 45 & 50 & 15 & 16 & 20 & 15 & 20 \\
\hline 0-5 méter & 8 & 30 & 10 & 14 & 8 & 1 & 5 & 16 & 6 & 8 & 10 & 11 & 6 & 2 & 1 & 2 & 0 & 2 & 1 & 1 \\
\hline 5-10 méter & 18 & 19 & 23 & 12 & 11 & 5 & 4 & 12 & 14 & 11 & 30 & 9 & 5 & 3 & 0 & 3 & 1 & 3 & 2 & 3 \\
\hline
\end{tabular}

\section{KÖVETKEZTETÉSEK ÉS JAVASLATOK}

A Peszéri-erdőben az általunk vizsgált erdőrészletekben a fahasználatok a bálványfa terjedésére pozitív hatással vannak, amit kvantitatív alapokon igazoltunk. Amennyiben a magtermő egyedek nem kerülnek időben eltávolításra, az egyes vágások a bálványfa felújulását és terjedését nagymértékben elősegítik. Fontos megemlíteni, hogy volt olyan vizsgált erdőrészlet, amelyben a téli tarvágást közvetlenül megelőző vegetációs periódusban a magtermő egyedek elölésre kerültek, de ezzel együtt is nagyságrendi tőszámemelkedés következett be az alapállapot felmérésben rögzített adatokhoz képest. Ez a tőszámnövekedés a talajban/ talajfelszínen található, a magbankot képező, előző évekből származó magokból fejődő egyedekre vezethető vissza. Javaslatunk szerint jóval a fahasználat elött szükséges a magtermő egyedek elölését végrehajtani. Rebbeck \& Jolliff (2018) ezt az időszakot (amíg a bálványfa magjai életképesek maradnak) 6 évben határozza meg, saját helyi tapasztalataink szerint már (2)-3 év alatt is töredékére csökken a csíraképes bálványfa magok száma a magbankban.

Az inváziós fafajok visszaszoritására tett törekvések esetében figyelmet kell fordítani a hatályos erdőtörvényben és végrehajtási rendeleteiben szereplő megkötésekre illetve lehetőségekre is. Ezek közül kiemelendő az éves erdőgazdálkodási tevékenység gyakorlása, 41 § (3) c) pont, ami szerint a természetes, természetszerü és származék természetességi alapelvárású erdőkben az „intenziven terjedő fafajok” eltávolitása nincs erdőtervi fahasználati előiráshoz kötve. Ez azt jelenti, hogy az inváziós faegyedek eltávolítása (lehetőség szerint előzetes elölés után) tulajdonképpen bármikor végezhető - egyéb termelés bejelentését követően. Fontos megemliteni a faanyagtermelést nem szolgáló üzemmódú erdők esetén a fakitermelés szabályai, 47 § (2) c) pontot is, amely szerint fakitermelés az intenziven terjedő fafajokra végezhető. Végül a felső három természetességi alapelvárású, természetvédelmi és / vagy Natura 2000 rendeltetésű erdők esetén az erdő egyes rendeltetéséhez, közérdekü funkciójához kapcsolódó különös erdögazdálkodási szabályok, $27 \S(1)$ c) illetve 28 § (1) c) pontját is érdemes figyelembe venni. Eszerint - többek között - az erdőnevelések tervezése és végrehajtása során fokozott figyelemmel kell lenni az intenzíven terjedő fa- és cserjefajok visszaszoritására. Az említett jogszabályokat figyelembe véve a bálványfa (és más inváziós fafajok) terjedésének megakadályozása vagy lassitása érdekében érdemes megfontolni a következőket:

- A nevelővágások (akár teljes) elhagyása, ha az a fahozamra (mennyiségi és minőségi szempontból) nincs érdemi hatással, jellemzően a gyenge fatermőképességü állományok esetében

- A nevelővágások több ütemben történő végrehajtása, ami biztosithatja a többszöri visszatérést: első alkalommal csak az inváziós fafajok szelektív visszaszoritása, a következö alkalommal a tényleges tervezett vágások kivitelezése. Ez azonban a fakitermelés többletköltségei miatt csak akkor lehet gazdaságilag racionális döntés, amennyiben figyelembe vesszük a bálványfa (és más inváziós fafajok) terjedésére visszavezethető jövőbeli többletköltségeket 
- A nevelővágások során az őshonos cserjeszint lehetőség szerinti megkímélése (a közelítőnyomhálózat kivételével a lehető legtöbb területrészen).

A tuskópászták kialakítása az előzetesen bálványfát is tartalmazó állományok felújitása során determinisztikusan kialakuló terjedési gócpontokat hoz létre, és a fafaj gyors visszaterjedését eredményezi. A Peszérierdőt veszélyeztető nyugati ostorfa, kései meggy és zöld juhar esetében is elmondható ugyanez, csak lokálisan kisebb jelentőséggel. A tuskók és gyökérmaradványok aprítása, majd elszállítása hosszabb távon valószínűleg költséghatékonyabb lehet, mint a bálványfa visszaszorítását szolgáló rendszeres beavatkozások. Javaslatunk szerint érdemes a jövőben elsősorban a felvevő ágazatokat (pl. bioetanol-, mulcs-, papírgyártás, biomasszaerőmü) támogatni és fejleszteni, illetve alaposabb piackutatásokat végezni.

Terepi megfigyeléseink alapján fontosnak tartjuk megemlíteni, hogy a mesterséges erdőfelújitások ápolásai során a bálványfa és más inváziós fafajok egyedei gyakran megmaradnak a sorokban. Ennek egyik lehetséges oka az, hogy a munkát végzők nem ismerik fel magabiztosan a növényeket. Ennél fogva érdemes lehet több időt fordítani a kézi ápolásokat végzők oktatására és ellenőrzésére is.

Gazdasági és/ vagy természetvédelmi értéket hordozó erdőkben a bálványfa visszaszorítása csak szelektív vegyszeres módszerekkel hatékony. Egybefüggő állományait viszont - gazdasági szempontokból is - érdemesebb minél hamarabb véghasználni, majd más fafajokkal mesterségesen felújítani. Mindkét megoldás illetve ezek kombinációja azonban már kis területeken is jelentős költségekkel járhat, így alkalmazásuk a jövőben valószínűleg csak egyes kiemelt projekthelyszíneken valósulhat meg. Fontos azonban kihangsúlyozni, hogy a mirigyes bálványfa elsősorban rövidtávon jelent kiemelkedő problémát, mert a magbankja viszonylag hamar kimerül. Emellett, a hazánkban szintén gyakori zoochor terjesztésű inváziós fafajokhoz - pl. a nyugati ostorfához és a kései meggyhez - képest nagy távolságokra csak nehezen tud eljutni. A Peszéri-erdőben az OAKEYLIFE projekt keretein belül zajló visszaszorítási törekvéseknek köszönhetően a bálványfa már tíz hektáros léptékben került eltávolításra olyan erdőállományokban, amelyekben korábban tömeges volt. A propagulumnyomás megszűntetésével, majd az (elhagyhatatlan) utókezelések kivitelezésével a fafaj viszonylag gyorsan, néhány év alatt eredményesen visszaszorítható egy adott területen. Ehhez azonban szükséges követni azokat a technológiai előirásokat, amelyek a hatékony irtására vonatkoznak, továbbá érdemes nagyobb figyelmet fordítani a részben általunk is tárgyaltakra az erdőgazdálkodási tevékenységek tervezése és végrehajtása során.

Végül fontos kitérni arra is, hogy az elmúlt évek kutatásai egy új, biológiai megoldást körvonalaznak, ami a publikus információk szerint sokkal hatékonyabb, illetve költséghatékonyabb lehet, mint az eddig alkalmazott módszerek. A bálványfa verticilliumos hervadására és a patogén természetvédelmi illetve gazdasági gyakorlatba való integrálására egyre nagyobb hangsúly helyeződik (lásd. pl. Kasson et al 2014, Lorenzini 2016, Maschek \& Halmschlager 2018, Pisuttu et al 2020). A fafaj - gyakran látványos - pusztulását a Peszéri-erdőben 2018-2019-ben közel 30 helyszínen rögzítettük. A KEFAG Zrt. által kezdeményezett és a NAIK által kivitelezett vizsgálatok pedig megerősítették, hogy a bálványfa egyedek elhalását a verticilliumos hervadás okozza (Lakatos et al 2020). A jelen tanulmányunkban szereplő erdőrészletek közül egyedül a Kunpeszér 6 B (kontroll) erdőrészletben volt tapasztalható tőszámcsökkenés (lásd. 2. táblázat). $A z$ itt található bálványfás foltok egy részénél egyértelműen látszott az egyedek teljes pusztulása, vagy folyamatban levő lombszáradása mind a lombkorona-, mind pedig az újulati szintben. A Peszéri-erdőben tett megfigyeléseink szerint a patogén a bálványfa eradikációjára valószínűleg nem képes, ugyanakkor jelentős mértékben csökkentheti a propagulumnyomást és az újulat vitalitását, vagyis lassíthatja, adott esetben megfékezheti a fafaj terjedését. 


\section{KÖSZÖNETNYILVÁNÍTÁS}

A vizsgálatok az OAKEYLIFE projekt és a Magyar Agrár- és Élettudományi Egyetem Környezettudományi Doktori Iskola programja keretén belül, továbbá az Innovációs és Technológiai Minisztérium Kooperatív Doktori Program Doktori Hallgatói Ösztöndij Programjának a Nemzeti Kutatási, Fejlesztési és Innovációs Alapból finanszírozott szakmai támogatásával készültek.

Köszönettel tartozunk a Kiskunsági Nemzeti Park Igazgatóságnak, a KEFAG Kiskunsági Erdészeti és Faipari Zrt.-nek és a Magyar Madártani és Természetvédelmi Egyesületnek a szakmai támogatásért. Külön köszönet illeti továbbá dr. Andrési Dánielt, Pongrácz Józsefet, Molnár Ábel Pétert, Mizsei Edvárdot, Kozma Botondot és Németh Imre bácsit a konzultációkért. Köszönjük továbbá a két anonim bíráló épitő megjegyzéseit, javaslatait.

\section{FELHASZNÁLT IRODALOM}

Csiszár Á. \& Korda M. (eds) 2017: Özönnövények visszaszoritásának gyakorlati tapasztalatai. 2. kiadás. Rosalia kézikönyvek 3. Duna-Ipoly Nemzeti Park Igazgatóság, Budapest

Erdélyi A., Hartdégen J., Molnár Á.P. \& Vadász Cs. 2019: A mirigyes bálványfa (Ailanthus altissima (Mill) Swingle) finomléptékủ elterjedésének vizsgálata archív és recens adatok alapján a Peszéri-erdőben. Tájökológiai Lapok 17(1): 75-84.

Erdélyi A., Hartdégen J., Malatinszky Á. \& Vadász Cs. 2021: Silvicultural practices as main drivers of the spread of Tree of Heaven (Ailanthus altissima (Mill.) Swingle). The 1st International Electronic Conference on Biological Diversity, Ecology and Evolution, Proceedings 68. https://doi.org/10.3390/BDEE2021-09467

Faragó S. 1964: A bálványfa. In: Lengyel Gy. (ed): Erdészeti Kutatások 60: 87-110.

Gencsi L. \& Vancsura R. 1992: Dendrológia. Mezőgazda Kiadó, Budapest

Kasson M.T., Short D.P.G., O'Neal E.S., Subbarao K.V., \& Davis D.D. 2014: Comparative pathogenicity, biocontrol efficacy, and multilocus sequence typing of Verticillium nonalfalfae from the invasive Ailanthus altissima and other hosts. Phytopathology 104(3): 282-292. https://doi.org/10.1094/PHYTO-06-13-0148-R

Kolossváry Sz. 1961: Adatok a kerekegyházai homokfásító kísérleti erdészet történetéből. In: Keresztesi B. és Kolossváryné Perényi M. (eds): Erdészeti Kutatások 57: 241-273.

Korda M. 2018: A Magyarországon inváziós növényfajok elterjedésének és elterjesztésének története I. In: Bartha D. (ed): Tilia vol. XIX.. Sopron, Soproni Egyetem EMK Növénytani Tanszék, 111-194.

Kota N.L., Landenberger R.E. \& McGraw J.B. 2007: Germination and early growth of Ailanthus and tulip poplar in three levels of forest disturbance. Biological invasions 9: 197-211. https://doi.org/10.1007/s10530-006-9026-4

Lakatos T., Kovács Cs., Tóth T., Andrési D. \& Bárány G. 2020: A bálványfa verticilliumos hervadása. Erdészeti Lapok 155(4): 113-114.

Lorenzini, G. 2016: Will a fungus save us from the Ailanthus invasion? Italian Journal of Mycology 45(1): 13-18. https://doi. org/10.6092/issn.2531-7342/6151

Maschek O. \& Halmschlager E. 2018: Effects of Verticillium nonalfalfae on Ailanthus altissima and associated indigenous and invasive tree species in eastern Austria. European Journal of Forest Research 137: 197-209. https://doi. org/10.1007/s10342-018-1099-y

Pisuttu C., Marchica A., Bernardi R., Calzone A., Cotrozzi L., Nali C., Pellegrini E. \& Lorenzini G. 2020: Verticillium wilt of Ailanthus altissima in Italy caused by $V$. dahliae: new outbreaks from Tuscany. iForest 13: 238-245. https://doi. org/10.3832/ifor3238-013

Radtke A., Ambraß S., Zerbe S., Tonon G., Fontana V. \& Ammer C. 2013: Traditional coppice forest management drives the invasion of Ailanthus altissima and Robinia pseudoacacia into deciduous forests. Forest Ecology and Management 291: 308-317. https://doi.org/10.1016/j.foreco.2012.11.022 
Rebbeck J., Hutchinson T., Iverson L., Yaussy D. \& Fox T. 2017: Distribution and demographics of Ailanthus altissima in an oak forest landscape managed with timber harvesting and prescribed fire. Forest Ecology and Management 401: 233-241. https://doi.org/10.1016/j.foreco.2017.06.050

Rebbeck J. \& Jolliff J. 2018: How long do seeds of the invasive tree Ailanthus altissima remain viable? Forest Ecology and Management 429: 175-179. https://doi.org/10.1016/j.foreco.2018.07.001.

Udvardy L. 2004: Bálványfa (Ailanthus altissima (Mill.) Swingle). In: Mihály B. \& Botta-Dukát Z. (eds): Biológiai inváziók Magyarországon. Özönnövények. TermészetBÚVÁR Alapitvány Kiadó, Budapest, 143-160.

Udvardy L. \& Zagyvai G. 2012: Mirigyes bálványfa (Ailanthus altissima (Mill.) Swingle). In: Csiszár Á. (ed): Inváziós növényfajok Magyarországon. Nyugat-magyarországi Egyetem Kiadó, Sopron, 13-16.

Zagyvai G. 2006: Fás szárú növények gyökérsarjképzése. Erdészeti Lapok 141(9): 277-279.

Érkezett: 2021. január 20.

Közlésre elfogadva: 2021. március 21. 